International Review of Research in Open and Distributed Learning Volume 21, Number 4

November - 2020

\title{
Zones of Agency: Understanding Online Faculty Experiences of Presence ${ }^{i}$
}

Anita Samuel, PhD

Uniformed Services University of the Health Sciences, Center for Health Professions Education, Maryland

\begin{abstract}
As instructors are forced to move their courses online, they are confronted by a sense of isolation and distance from their learners. Research has shown that feelings of loneliness are mitigated when presence is created in the online environment. An interpretive phenomenological analysis was conducted at a public university in the United States to answer the question: What are the determinants of presence for instructors in online teaching? Twenty-five online instructors from various disciplines, with diverse levels of experience teaching online, were recruited for the study. Interviews, analysis of course syllabi, and observations of course sites revealed five determinants of presence for online instructors: content, format, strategies, technology, and students. The crucial factor in deciding an instructor's experience of presence was the degree of agency instructors had over these determinants. This paper introduces the Zones of Agency for Online Instructors model and describes how the model can be used to enhance instructors' experiences of presence.
\end{abstract}

Keywords: presence, online education, faculty development, determinants of presence 


\section{Introduction}

The online learning environment is a mediated environment that is characterized by the isolation that arises from distance (Kim, Kwon, \& Cho, 2011; Lee \& Choi, 2011; Moore, 1993). In this environment, presence plays a crucial role in creating participant enjoyment and involvement (Lombard \& Ditton, 1997). Presence in a mediated environment has been variously defined as a sense of "being there" (Slater, 1999, p.2), "being connected and together" (Sung \& Mayer, 2012, p. 1739), and being "accessible, available, and subject to one another" (Goffman, 1963, p. 22). The concept of presence in online education has been studied extensively. Some of the concepts and frameworks that have been developed are social presence; telepresence; the community of inquiry framework, which draws together social, cognitive, and instructor presence (Garrison, Anderson, \& Archer, 1999); and the being "there" for the online learner model (Lehman \& Conceição, 2010). These concepts and frameworks, in the context of online education, share a learnercentered focus. It is the learner's experience of presence that is studied, and the frameworks are designed to enhance the learner's experience of presence in the online learning environment.

What is generally overlooked is an acknowledgement that the instructor in an online environment is also a participant in the mediated environment and, therefore, equally impacted by presence or the lack thereof. Research has shown that a lack of face-to-face interaction with students negatively affects instructor satisfaction with online teaching (Lloyd, Byrne, \& McCoy, 2012; Mills, Yanes, \& Casebeer, 2009; Shea, 2007; Wasilik \& Bolliger, 2009). Childers and Berner (2000) and Henning (2012) further note that the sense of isolation instructors experience could potentially affect their motivation to teach in the online environment. However, the instructor experience of isolation has not been widely researched, and literature in this area has been limited to personal anecdotes (Bair \& Bair, 2011). Bair and Bair (2011), reflecting on their own experiences in online instruction, comment that the lack of physical interaction resulted in their experience of isolation. They felt that they were merely "looking at the computer screen rather than at human faces" (p. 6).

While presence has been found to mitigate learners' experiences of isolation, it has not been studied in the context of instructors. As educational institutions are forced to move their programs online, it is essential to understand what factors affect instructors' experiences of presence. To this end, a qualitative study was conducted on instructors' experiences of presence. The study findings helped identify the determinants of presence for instructors in the online environment. The research question addressed was: What are the determinants of presence for instructors in online teaching?

\section{Conceptual Framework}

Lombard and Ditton (1997) synthesized various conceptualizations of presence and holistically defined presence as a "perceptual illusion of non-mediation" (Presence Explicated section, para. 1). With presence, the mediated environment appears transparent and abstracted from the user. In essence, the mediated environment disappears, and participants feel that they are interacting in a face-to-face encounter.

Lehman and Conceição (2010) identify six determinants of presence in their framework for designing online courses with a sense of presence: content, format, strategies, instructor role, technology, and support. From 
a learner-centered perspective, they contend that the six determinants can help "guide the creation of a sense of presence in the online environment" (p. 26). These determinants of presence formed the conceptual framework of this study, as it sought to explore what factors would influence instructors' sense of presence.

\section{Methodology}

This study was conducted using an interpretive phenomenological analysis (IPA) approach, since it focused on the specific phenomenon of presence, and the experiences and perceptions of participants regarding this phenomenon. IPA is based on the theoretical principles of phenomenology, hermeneutics, and idiography (Smith, Flowers, \& Larkin, 2009). The lived experiences of the participants are studied using a double hermeneutic and idiographic approach of focusing on one participant at a time. IPA seeks the essence of a particular experience across different participants and focuses on vertical generalizability, where findings from one context could prove useful in other situations within similar contexts (Yardley, 2008).

\section{Participant Sample}

To ensure homogeneity of the instructional context, all participants were recruited from a single 4-year public university in the United States Midwest. This guaranteed that all participants had access to the same online learning platform, support services, and administrative policies. Research has shown that instructors from different disciplines differ in their interaction styles (Smart \& Umbach, 2007), dialogic behavior (Gorsky, Caspi, Antonovsky, Blau, \& Mansur, 2010), and evaluation strategies (Smith, Heindel, \& TorresAyala, 2008). Studies have also shown that instructors' perceptions of online education vary with their experience levels (Ulmer, Watson, \& Derby, 2007). These factors were taken into account, and a purposive sampling process was implemented to achieve a broad representation of participants across disciplines and experience levels. Biglan's (1973) model categorizes disciplines as hard/soft, pure/applied, and life/nonlife. For this study, Biglan's model was modified into four main categories of pure/hard, pure/soft, applied/hard, and applied/soft. The Appendix shows how the University's academic course offerings were classified. Instructors who had taught more than three fully-online courses were classified as experienced, and instructors who had taught up to three fully-online courses were classified as novice instructors.

A matrix (see Table 1) was created to categorize participants based on their disciplines and experience levels and to ensure that a minimum of two participants were represented in each quadrant. Instructors at the university who had taught fully-online graduate or undergraduate courses during one academic year were identified and invited via email to participate in the study. A total of 25 participants were distributed across the matrix as shown in Table 1 . In order to maintain anonymity, gender-neutral identifiers of $P \#$ were assigned to the participants based on the order in which their interviews were conducted. 
Table 1

Participant Distribution Matrix

\begin{tabular}{lll}
\hline & Experienced instructor & Novice instructor \\
\hline Pure/Hard & 2 participants & 3 participants \\
Applied/Hard & 4 participants & 3 participants \\
Pure/Soft & 3 participants & 4 participants \\
Applied/Soft & 4 participants & 2 participants \\
\hline
\end{tabular}

\section{Study Design}

Data were collected from three sources in this study: course syllabi developed by the participants (2 per participant), semi-structured interviews, and observations of participants' online course sites. These three data sources provided rich detail and enabled triangulation of the data. Each participant emailed the researcher two course syllabi, which were analyzed prior to the participant's interview. The interviews were 60-90 minutes in duration and were audio-recorded. Observations were limited to online courses that were underway at the time of the interviews, and five of the participants consented to being observed. The observation spanned 12 weeks (i.e., one academic semester). During the observations, detailed notes were taken, guided by the research question. All three sources of data were treated as textual data and analyzed as prescribed by IPA. Transcripts were read, themes were identified and clustered, followed by the tabulation of the themes in an organized format.

\section{Findings}

All of the transcripts were analyzed using the six determinants of presence identified by Lehman and Conceição (2010). The findings are presented through the lens of the six determinants: content, format, strategies, technology, support, and student role.

\section{Content}

P12: I love the topic matter, so it's easy to be enthusiastic. I think it makes a big difference for the dynamic with the students, so I love the response that that gets.

P6: I like the course.

P4: [It] probably helps that I really like the subject material, and it changes every year. I always have to update it, and it's a nice excuse to spend time doing something that I would want to do anyway, which is learning more about seeing how the science is changing year after year.

Course content emerged as a clear determinant of presence for the participants. When participants were teaching content that they were passionate about, they felt involved and engaged. Love of the subject matter ensured that participants remained motivated to teach and engaged with the course irrespective of other factors. 
However, participants were not always consulted on what courses they taught. At times they were required to teach courses that they were not familiar with, which caused them anxiety. P15 reported that, "This semester I don't love either of the classes I'm teaching. It's more of a drag than I've had in a long time. So I think I do feel less inclined to get online and interact." P19 faced restrictions in her teaching, as she was required to implement strategies and assessments prescribed by her department. This led her to admit that, "some of the stuff, I don't believe in myself. But I'm a representative teacher [of the department]. So now I'm having to defend what I consider bunk in the first place and to do it with authority."

When they connected with the course content, participants experienced presence through the content of the course. When they did not believe in the content, however, it clouded their online teaching experience and affected their experiences of presence online.

\section{Format}

P1: When I grade, I tend to try to put a professional or personal comment or tone to it.

Online courses are broadly taught in two main formats: self-paced or instructor-led. Self-paced courses are created by the instructor and then implemented on "auto-pilot." Students allocate their own study time and decide on the pacing of the course (Tullis \& Benjamin, 2011). They independently access the materials and submit assignments. Interaction between the instructor and the students is infrequent and is usually limited to the feedback instructors provide on assignments. Instructor-led courses are more interactive, and the instructor plays a more active role in leading and facilitating the course. These online courses include both synchronous and asynchronous interactions, such as video conferences and discussion boards.

All of the participants in this study felt a greater sense of presence when they played an active role in their courses. They talked about knowing their students better and experiencing presence when they provided individual feedback. As P2 expressed it, "So then, that gave me a chance after they [wrote an essay] to then write them and say 'You did a wonderful job, but'; and then they'd think about it and write back, and then we started connecting." Instructors viewed the process of providing feedback as an opportunity to show their commitment and concern for student success. Sixteen (64\%) of the participants talked about interacting with individual students through emails or discussion posts. Course formats that allowed for increased interaction between the instructor and the learners created a greater sense of presence for the instructors.

\section{Strategies}

P24: When you start reading their responses and how they're thinking of dealing with a situation, you do get a feel for their personalities.

P22: I'm very connected with [the students] by their projects because I'm reading about them, or chatting about them; they're talking about them, I'm giving them feedback on them.

P5: Through their assignments, every week they're saying, "well here's something that happened to me at work," "here's what I'm going through," "I'm really interested in this." So, I'm getting to know them pretty well. 
The pedagogical strategies that instructors incorporated in their courses played a significant role in their personal experiences of presence. Essays and open-ended writing tasks effectively connected participants to their students on a deeper and more meaningful level. In addition to essays, quizzes were included as a form of assessment. Auto-graded multiple-choice and short-answer quizzes were used in the courses. The auto-graded multiple-choice quizzes provided opportunities to check student knowledge, but their use created no sense of presence for the participants. Short answer quizzes that required manual grading, however, enabled P13 to engage with the learners.

Many participants included discussion forums in their courses. P12 taught an introductory undergraduate level class with 175-200 students and incorporated discussions in at least four of the course modules to encourage interaction. She found it rewarding for herself and her students. P1 revealed that "I'm very engaged in the discussion boards." However, not all of the participants' experiences with discussion boards were positive. P6 found discussion boards to be "an ineffective means to stimulate conversation. A bad proxy for a discussion." P19 noted that "online you [students] are required to enter the conversation because you're required to have so many posts at certain points of time; and they need to be substantive, they need to be productive." P19 considered this an artificial form of engagement. For some instructors, therefore, these discussion posts did not draw them into the online environment and did not enhance their experiences of presence in any way.

\section{Technology}

P3: I watch these little video essays...and I think they're interesting and fun. And, so then I feel like [creating videos] is interesting and fun for me.

P17: I just found new software this weekend...so I'm very excited about making digital flashcards for my...class.

P5: [T] hat computer work over the years, I like to do that. It's kind of fun, it's a challenge, so I enjoy that part of it. So, I think I've had a positive experience.

P19: A love of the technology itself is critical. Really wanting to have fun with Internet tools.... I think it changes the experience. I really do.

Online education is built on technology, and participants' relationship and emotional response to technology was an important factor in their perceptions and experiences of presence. Instructors who were comfortable using technology had more positive online experiences. They used technology to create new and interesting course materials, which they found to be an engaging and rewarding experience. Half (52\%) of participants enjoyed working with technology and engaged with their online courses at a deeper level, thereby experiencing presence. However, this experience was not shared by all of the participants. P9 stated that, "I like technology. I don't like technology when it doesn't work, or when people change things, and I have to relearn."

The greater the challenges they experienced with technology, the more distant instructors felt in their courses. P1 spoke of how she had adopted Second Life: 
So in Second Life, it probably impacted me more than the students. The amount I got frustrated...the amount of time [I] spent on dealing with the technology issues that took away from me focusing on the students' learning and understanding and appreciating the content.

For P25 the learning management system (LMS) was "a universe unto itself, and there's somebody who understands it" but, he did not. For P25, the LMS was merely "a tool. I would never sit down and have a good time playing with the computer."

\section{Support}

P5: I just thought it was very helpful.

P2: If I go to the LTC [Learning Teaching Center] with a question, they're absolutely wonderful.... I don't know what I'd do without them.

P1: [The] one-on-one attention I got from [my mentor], it improved my online and improved my face-to-face classes.

The participants had access to a variety of institutional-support resources, including 24-7 helpdesk access, training sessions, and technical support. Support was also provided through mentors. P1, P4, and P19 had highly valued mentor relationships. They felt that their mentor was the most significant contributor to their success in online teaching (see also Vaill \& Testori, 2012). Departmental peer groups were available to P3 and P6, and discussion topics ranged from online teaching experiences to course materials and assessment strategies. Beyond the institution, $\mathrm{P} 4$ and $\mathrm{P} 23$ found support through national communities of practice, where members shared resources to enhance their teaching practice. Interestingly, while support and training enhanced the teaching practices of the participants, none of the instructors associated their training with their experiences of presence.

\section{Student Role}

P21: I act, there is a reaction, and that informs what I'm doing. I can't explain something to a wall because I can't understand what's being received and whether I'm being clear or understood. And if I don't get that back, then I don't know where to go.

P7: [I]t takes two people to have a conversation.

Lehman and Conceição's (2010) framework identifies the instructor role as a determinant of presence for learners. For instructors, students were identified as a strong determinant of presence. Student participation within the online learning space strongly impacted the instructors' experiences of presence. When students actively engaged with the instructor, the content, activities, and other students, the participants were drawn in and felt connected, engaged, and affirmed. For participants, it was the students' interaction with them and among themselves that heightened their experiences of presence. The most disconcerting experience for the participants was when students were non-responsive. P14 noted that an instructor had "to be very reliant on [their] students for that back and forth. So in that regard, if [the students] don't do it, you're stuck." When students chose not to respond, it left an impression that "there's a non-entity there" (P21). 
P24 commented that, "I saw that they [students] were engaging in these discussions, and they really gave the impression that they really cared about the topics." Conversely, when there was no activity, P21 noted that, "I don't know whether I'm succeeding in engaging people if I'm getting nothing back. Online, if they don't respond to me, I have nothing."

While students' interaction through emails and discussion posts was important, it was the quality rather than the quantity of interactions that was important to the participants. P6 received the desired number of discussion board posts with comments, such as "good point," which left him feeling dissatisfied. P8, on the other hand, enjoyed the experience of interaction due to the motivation and high quality of student posts. The participants accepted that there was a spectrum of student engagement. On one end of the spectrum were students who were very engaged, and on the other end were students who "vanished." The instructors' sense of presence was impacted by the level of student participation. When students disappeared, the participants also disengaged.

Although the activities that the instructors included in their courses affected their experiences of presence, the best and most interactive activities could only succeed when students responded. It was students' behaviors that the participants associated most with their experiences of presence.

\section{Discussion}

Online instructors' experiences of presence were affected by five major determinants of presence: content, technology, student role, format, and strategies. The degree of agency instructors had over these determinants affected their experiences of presence in their online teaching environments. The Zones of Agency for Online Instructors model was developed to show the relationship between instructors and their level of agency over the determinants. The instructor is the focus and is placed in the center of the model. Figure 1 represents the zones of agency that surround an online instructor. 


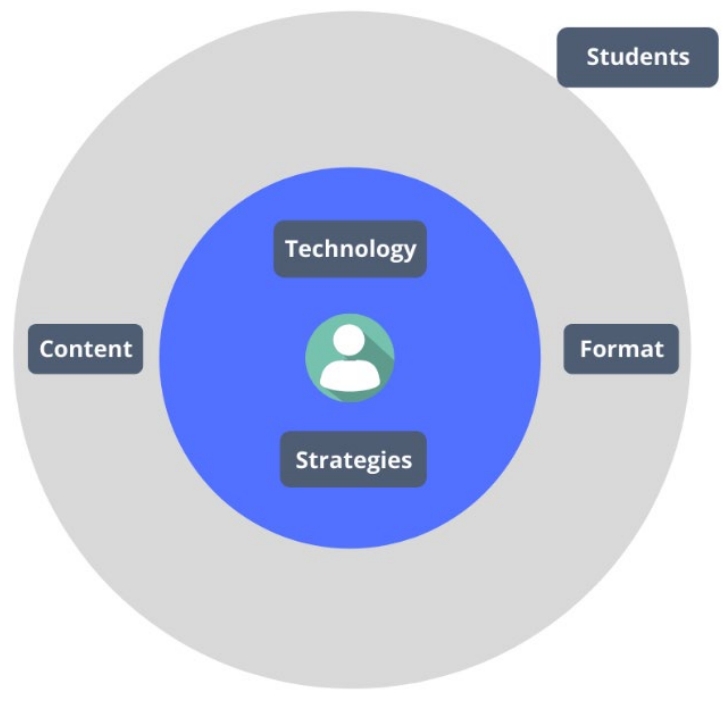

Figure 1. The Zones of Agency for Online Instructors model.

Determinants that lie close to the instructor (i.e., in the blue circle) represent elements that the instructor has the most agency over and can use to create a personal sense of presence. The further away from the instructor the determinants are (i.e., in the grey circle and in the periphery), the less agency the instructor has over them. In this study, instructors designed the pedagogical strategies they used in their online courses. They had a high degree of agency in their choice of pedagogical strategies. When an instructor designed a course, they had the discretion to decide what kind of activities to incorporate, thereby providing opportunity for enhanced experiences of presence. Technology is another determinant where the instructors could exert their agency. Familiarity with technology, gaining practice using technology, and then comfortably incorporating technology in their online courses established a sense of presence for the instructors. Instructors could also choose what technologies to incorporate in their courses, thereby adding to their agency.

Content and format are in the outer zone of agency (i.e., the grey circle). Instructors did not have a high degree of agency over these determinants, although content and format affected their experiences of presence. Course formats were decided at the institutional or departmental level, and instructors were given courses to teach in specific formats; for example, self-paced or instructor led. Within these formats, the participants could define activities that create more interaction with the learners, thereby creating a personal sense of presence. Course content, such as the topic of the course, course goals and objectives, and course materials were defined at the departmental level; and most participants did not have much of control over content. However, the choice of materials fell under the instructors' purview and contributed to their sense of presence.

Students were the most impactful determinants of presence for the instructors; yet, they are on the periphery of the instructor's zones of agency. While the instructors could create opportunities for interaction with the students, it was up to the students to engage with them. The instructors' experiences of presence were strongly affected both positively and negatively by students' interactions with them in their courses. 


\section{The Scope of the Zones of Agency for Online Instructors Model}

The strength of the Zones of Agency for Online Instructors model lies in its adaptability. The model can be restructured in different ways to represent different teaching environments. The organization of the determinants of presence depicted in Figure 1 is specific to a learning environment where instructors have autonomy over their choice of pedagogical strategies and some autonomy over content selection and course format. However, if the institution were more prescriptive, and instructors were provided with fully developed courses and had no autonomy over any course choices, the model could be modified to reflect that teaching environment, as presented in Figure 2. Instructors do maintain some agency over pedagogical strategies and technology (in the grey circle), and they can shape their personal experiences with the technology they use and the ways they reach out to their learners. In this environment, content and format move to the periphery, outside the instructor's zone of agency. While depicting the instructors' zones of agency, Figure 2 also conveys the instructors' reduced experiences of presence when they have less agency over the determinants of presence.

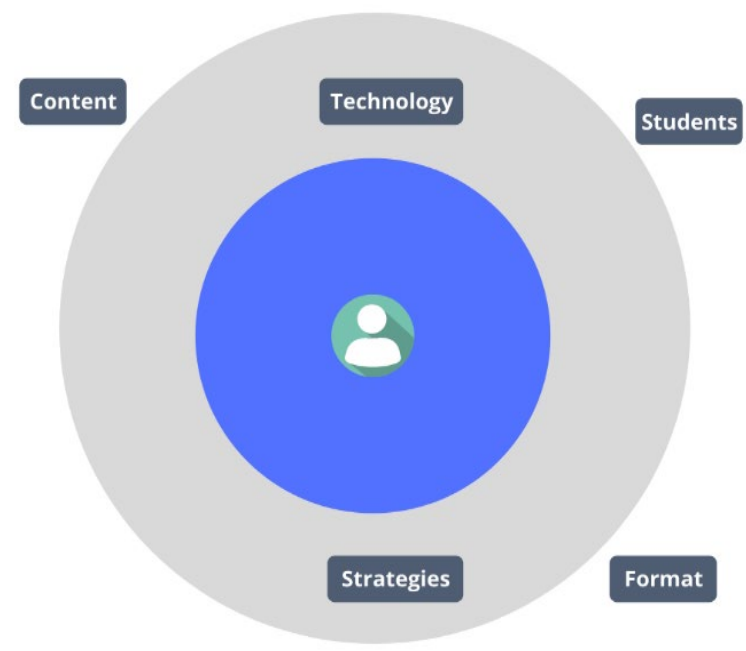

Figure 2. An adaptation of the Zones of Agency for Online Instructors model to depict a prescriptive course environment.

A program where instructors can determine the entire design of their course is represented in Figure 3. With such a high degree of agency, an instructor's experiences of presence would be elevated compared to the previous scenarios. In all situations, however, students remain on the periphery of an instructor's zones of agency, while they are the most impactful factor. 


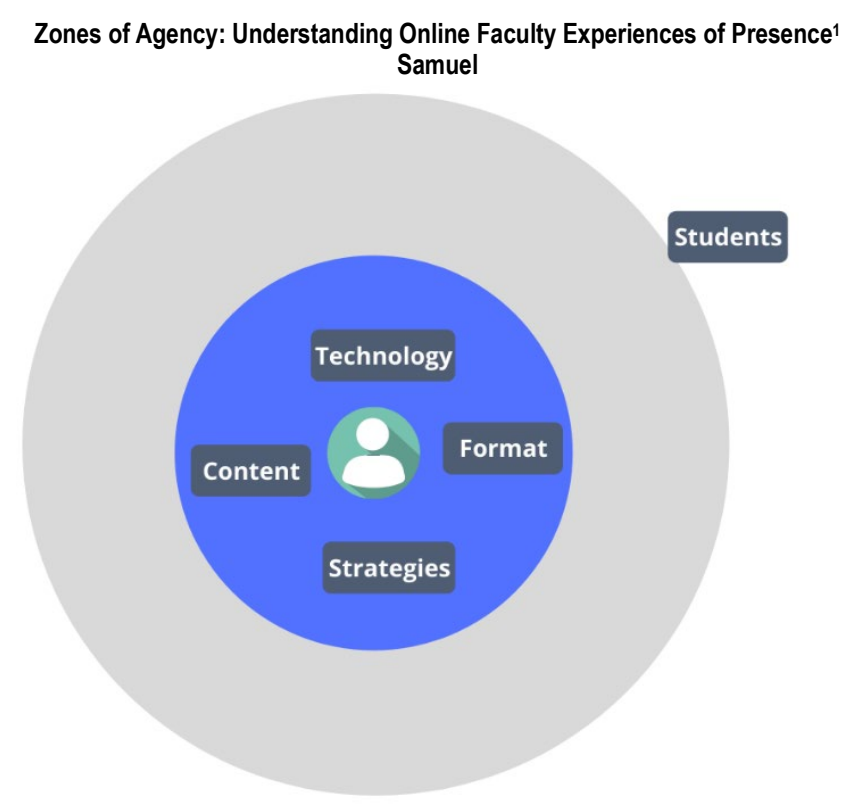

Figure 3. An adaptation of the Zones of Agency for Online Instructors model to depict a teaching environment where instructors have a high degree of agency.

\section{Implications for Theory and Practice}

The Zones of Agency for Online Instructors model is a simple but effective way to prepare instructors for transitioning to online teaching or new instructors joining an institution. As part of instructor orientation, this model can clearly express what is provided by the institution, how much autonomy instructors have, and what they should expect from online teaching.

Based on the study results, Figure 3 represents an effective combination of autonomy. The instructors were most satisfied when they had more agency over the course format, content, and strategies. Other representations of the model, such as Figure 2, can provide institutions with an opportunity to understand why their instructors may not be engaging with their online courses at an optimal level. The model provides room for critical reflection on how an institution's online teaching practices are organized and how that may affect instructors' experiences of presence. The model can also provide the basis for suggestions for improvement.

\section{Study Limitations and Future Research}

This study is limited by the participant sample. Since participation in this study was voluntary, there was an inevitable self-selection bias that must be acknowledged. Furthermore, the employment status of the instructors (e.g., tenured, adjunct and assistant professor, lecturer) was not considered as a variable in this study. Inclusion of this variable may have highlighted other determinants of presence for the instructors, such as job security or the hierarchy within the organization. Another variable that was not included was that of instructors' workload. The number of courses that an instructor teaches at one time may affect their experiences of presence. Finally, student demographics were not considered as a variable in this study. It would be interesting to explore whether differences in student demographics affect their position in the 
zones of agency model. The influence of employment status and workload should also be considered in future research. Future research replicating this model in different institutions should be conducted to verify its applicability and relevance beyond the study context.

\section{Conclusion}

The literature on online learning is highly focused on student experiences. However, as instructors are forced to move their courses online, they should be considered as equal participants in the online environment. In this research, instructors' experiences were at the center, and the study aimed to understand the elements that contributed to instructors' sense of presence. The findings from this study indicate that instructors' sense of presence was dependent on the levels of agency they had over five determinants of presence: content, format, technology, strategies, and students.

The Zones of Agency for Online Instructors model can be adapted to represent the degree of agency online instructors have within specific institutions. It provides a quick snapshot of how online course design and delivery functions within an institution, and it immediately conveys instructor experiences of presence within that specific representation of the model. At an institutional level, this model can be a valuable tool to understand and enhance instructor experiences of presence and engagement in online courses. 


\section{References}

Bair, D. E., \& Bair, M. A. (2011). Paradoxes of online teaching. International Journal for the Scholarship of Teaching and Learning, 5(2), 1-15. https://doi.org/10.20429/ijsotl.2011.050210

Biglan, A. (1973). Relationships between subject matter characteristics and the structure and output of university departments. Journal of Applied Psychology, 57(3), 204-213.

https:/doi.org/10.1037/hoo34699

Childers, J. L., \& Berner, R. T. (2000). General education issues, distance education practices: Building community and classroom interaction through the integration of curriculum, instructional design, and technology. The Journal of General Education, 49(1), 53-65.

https:doi.org/10.1353/ige.2000.0001

Garrison, D. R., Anderson, T., \& Archer, W. (1999). Critical inquiry in a text-based environment: Computer conferencing in higher education. The Internet and Higher Education, 2(2-3), 87105. https://doi.org/10.1016/S1096-7516(00)00016-6

Goffman, E. (1963). Behavior in public places: Notes on the social organization of gatherings. New York, NY: The Free Press.

Gorsky, P., Caspi, A., Antonovsky, A., Blau, I., \& Mansur, A. (2010). The relationship between academic discipline and dialogic behavior in Open University course forums. The International Review of Research in Open and Distance Learning, 11(2), 49-72.

https://doi.org/10.19173/irrodl.v11i2.820

Henning, T. B. (2012). Writing professor as adult learner: An autoethnography of online professional development. Journal of Asynchronous Learning Networks, 16(2), 9-26. Retrieved from https://www.learntechlib.org/p/132462/

Kim, J., Kwon, Y., \& Cho, D. (2011). Investigating factors that influence social presence and learning outcomes in distance higher education. Computers \& Education, 57(2), 1512-1520.

http://dx.doi.org/10.1016/j.compedu.2011.02.005

Lee, Y., \& Choi, J. (2011). A review of online course dropout research: implications for practice and future research. Educational Technology Research and Development, 59(5), 593-618. https://doi.org/10.1007/s11423-010-9177-y

Lehman, R. M., \& Conceição, S. C. O. (2010). Creating a sense of presence in online teaching: How to "be there" for distance learners. San Francisco, CA: Jossey-Bass.

Lloyd, S. A., Byrne, M. M., \& McCoy, T. S. (2012). Faculty-perceived barriers of online education. MERLOT Journal of Online Learning and Teaching, 8(1). Retrieved from https://jolt.merlot.org/vol8no1/lloyd 0312.pdf 
Lombard, M., \& Ditton, T. (1997). At the heart of it all: The concept of presence. Journal of ComputerMediated Communication, 3(2). http:/doi.org/10.1111/j.1083-6101.1997.tb00072.x

Mills, S. J., Yanes, M. J., \& Casebeer, C. M. (2009). Perceptions of distance learning among faculty of a college of education. MERLOT Journal of Online Learning and Teaching, 5(1), 19-28. Retrieved from https://jolt.merlot.org/vol_5no1/mills_0309.pdf

Moore, M. G. (1993). Theory of transactional distance. In D. Keene (Ed.), Theoretical principles of distance education (pp. 22-38). New York, NY: Routledge.

Shea, P. (2007). Bridges and barriers to teaching online college courses: A study of experienced online faculty in 36 colleges. Journal of Asynchronous Learning Networks, 11(2), 73-128. http://dx.doi.org/10.24059/olj.v11i2.1728

Slater, M. (1999). Measuring presence: A response to the Witmer and Singer presence questionnaire. Presence: Teleoperators and Virtual Environments, 8(5), 560-565. https://doi.org/10.1162/105474699566477

Smart, J. C., \& Umbach, P. D. (2007). Faculty and academic environments: Using Holland's theory to explore differences in how faculty structure undergraduate courses. Journal of College Student Development, 48(2), 183-195. https://doi.org/10.1353/csd.2007.0021

Smith, G. G., Heindel, A. J., \& Torres-Ayala, A. T. (2008). E-learning commodity or community: Disciplinary differences between online courses. The Internet and Higher Education, 11(3-4), 152-159. https://doi.org/10.1016/j.iheduc.2008.06.008

Smith, J. A., Flowers, P., \& Larkin, M. (2009). Interpretative phenomenological analysis: Theory, method, and research. Thousand Oaks, CA: Sage.

Sung, E., \& Mayer, R. E. (2012). Five facets of social presence in online distance education. Computers in Human Behavior, 28(5), 1738-1747. https://doi.org/10.1016/j.chb.2012.04.014

Tullis, J. G., \& Benjamin, A. S. (2011). On the effectiveness of self-paced learning. Journal of Memory and Language, 64(2), 109-118. https://doi.org/10.1016/j.jml.2010.11.002

Ulmer, L. W., Watson, L. W., \& Derby, D. (2007). Perceptions of higher education faculty members on the value of distance education. The Quarterly Review of Distance Education, 8(1), 59-70. Retrieved from http://faculty.weber.edu/eamsel/Research\%20Groups/Online\%20Learning/Umer\%20et\%20al.\%20(2007).pdf

Vaill, A. L., \& Testori, P. A. (2012). Orientation, mentoring and ongoing support: A three-tiered approach to online faculty development. Journal of Asynchronous Learning Networks, 16(2), 111-119. Retrieved from https://www.learntechlib.org/p/132461/. 
Wasilik, O., \& Bolliger, D. U. (2009). Faculty satisfaction in the online environment: An institutional study. The Internet and Higher Education, 12(3-4), 173-178.

https://doi.org/10.1016/j.iheduc.2009.05.001

Yardley, L. (2008). Demonstrating validity in qualitative psychology. In J. A. Smith (Ed), Qualitative psychology: A practical guide to research methods (2nd ed., pp. 235-251). London, UK and Los Angeles, CA: Sage 


\section{Appendix}

Table A1

Classification of the University's Academic Course Offerings

Pure disciplines

\begin{tabular}{|c|c|}
\hline Hard sciences & Soft sciences \\
\hline $\begin{array}{l}\text { Astronomy } \\
\text { Physics } \\
\text { Mathematical sciences } \\
\text { Mathematical statistics } \\
\text { Geosciences } \\
\text { Chemistry \& biochemistry } \\
\text { Geography }\end{array}$ & $\begin{array}{l}\text { Africology } \\
\text { American Indian studies } \\
\text { Anthropology } \\
\text { Arabic } \\
\text { Latino studies } \\
\text { Lesbian, gay, bisexual \& transgender } \\
\text { studies } \\
\text { Linguistics } \\
\text { Art history } \\
\text { Celtic studies } \\
\text { Chinese } \\
\text { Classics } \\
\text { English } \\
\text { Ethnic studies } \\
\text { French } \\
\text { German } \\
\text { Spanish } \\
\text { Hebrew Studies } \\
\text { History } \\
\text { Japanese } \\
\text { Jewish Studies } \\
\text { Russian } \\
\text { Scandinavian Studies } \\
\text { Women's studies } \\
\text { Master's in language, literature, and } \\
\text { translation } \\
\text { Philosophy } \\
\text { Sociology } \\
\text { Communication } \\
\text { Comparative literature } \\
\text { Urban studies } \\
\text { Political science } \\
\text { Psychology } \\
\text { Music } \\
\text { Film, video, animation, \& new genres } \\
\text { Film studies } \\
\text { Foreign languages \& literature } \\
\text { Dance } \\
\text { Art \& design }\end{array}$ \\
\hline
\end{tabular}


Communication sciences \& disorders

Global studies

\begin{tabular}{|c|c|}
\hline Hard sciences & Soft sciences \\
\hline $\begin{array}{l}\text { Mechanical engineering } \\
\text { Architecture } \\
\text { Atmospheric science } \\
\text { Electrical engineering } \\
\text { Industrial \& manufacturing } \\
\text { engineering } \\
\text { Biomedical sciences } \\
\text { Conservation / Environmental } \\
\text { sciences } \\
\text { Computer science } \\
\text { Kinesiology } \\
\text { Biological sciences } \\
\text { Information studies }\end{array}$ & $\begin{array}{l}\text { Business administration } \\
\text { Business management } \\
\text { Theatre } \\
\text { Music education } \\
\text { Curriculum \& instruction } \\
\text { Educational policy \& community studies } \\
\text { Educational psychology } \\
\text { Exceptional education } \\
\text { Library \& information sciences } \\
\text { Translation \& interpreting } \\
\text { Economics } \\
\text { Nursing } \\
\text { Therapeutic recreation } \\
\text { Public administration } \\
\text { Social work } \\
\text { Nonprofit administration } \\
\text { Nursing } \\
\text { Occupational therapy } \\
\text { Public health } \\
\text { Journalism, advertising, \& media Studies } \\
\text { Criminal justice } \\
\text { Health care administration } \\
\text { Counseling } \\
\text { Health sciences }\end{array}$ \\
\hline
\end{tabular}

\section{Athabasca University}

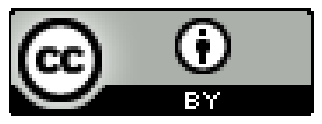

\footnotetext{
${ }^{i}$ The opinions and assertions expressed herein are those of the author(s) and do not necessarily reflect the official policy or position of the Uniformed Services University or the Department of Defense.
} 